\title{
Affective Learning Strategies Used to Improve Students' English Reading Comprehension by College Students
}

\author{
Afdaleni \\ School for Foreign Language Haji Agus Salim Bukittinggi \\ West Sumatera, Indonesia \\ afdaleni_09@yahoo.com
}

\begin{abstract}
Knowing the appropriate LLS in an important aspect to make learning successful. There are some language learning strategies that can be used by college students. The study is aimed at investigating the affective learning strategies by college students in learning English Reading Comprehension. The study focuses on investigating affective learning strategies used in learning English Comprehension for college students. The study is descriptive qualitative approach. The participants are about 42 students who have studied English reading comprehension at college. Data are collected through questionnaire of SILL by Oxford, interview and observation. The study shows that there are some affective learning strategies used by students in English such as learning anxiety, encouraging yourself and taking emotional temperature with different category. Then there are some influential factors to use appropriate Language Learning Strategies such as motivation, type of task and learning material.
\end{abstract}

Keywords - affective, learning strategy, reading comprehension

\section{INTRODUCTION}

Successful in learning English as a foreign language is influenced by individual differences of the students in many factors; intrinsic and extrinsic ones. They can be motivation, intelligence, aptitude, interest, learning strategy, teacher, media, and some others. Among the factors mentioned before, learning strategy is considered as one of the main influencing factors for the students' success in reading comprehension. Rubin (1982:3) and Oxford (1990:2) state that the language learner is one of the important factors in their success in acquiring the language. It is stated that the learners in acquiring the language use learning strategy that may determine their success in their language acquisition. It means that the learner should know many things about learning the language. In other words learning strategy is considered important for the students in acquiring, producing and comprehending the new language.

As stated by (Rubin 1987; Cohen 1998; Oxford, 1990), using language learning strategy could make the students more effective in learning language.In relation to this, Oxford (1989) states that most of teachers are not generally aware of their students' learning strategy and the students are no aware of the strategy; they cannot take advantage of the full range of available strategies. Then, most of teachers are not generally aware of their students' learning strategies, the students are not aware of the strategies, they cannot take advantage of the full range of available strategies (Oxford, 1984).

Learning strategy is defines as the strategy that contributes to he development of the language system used by learner and give effects to the learning directly (Rubin, 1987) and according to O'Malley and Chamot (1990) language learning strategy is special thoughts or behaviours used by individuals to help them comprehend or new information and also language learning strategy is the strategy used by the learner in dealing with target language (Keshavarz, 1994).

There are some experts who have classified language learning strategy. Oxford (1990) classifies Language learning strategies into two groups; direct strategies are memory; cognitive, and compensation strategy and indirect strategies are metacognitive, affective and social strategies. There are a number of strategy sets of affective strategies that consist of lowering your anxiety; has a physical and a mental components (using progressive relaxation, deep breathing or mediation, using music and laughter), encouraging yourself; often forgotten by language learners who expect encouragement mainly from other people and not realize they can provide their own, taking your emotional temperature; help learners to assess their feelings, motivation, and attitudes and in many cases, to relate them to language tasks.

Table 1: Affective learning strategies in English reading comprehension

\begin{tabular}{|c|c|l|l|}
\hline No & Items strategy & Strategy set & Strategy group \\
\hline & $\begin{array}{c}\text { Using progressive relaxation, deep } \\
\text { breathing or mediation }\end{array}$ & \multirow{2}{*}{ Lowering your anxiety } & \multirow{2}{*}{ Affective Strategies } \\
\hline & Using music & & \\
\hline & Using laughter & & \\
\hline
\end{tabular}


Table. 1. Cont

\begin{tabular}{|c|c|l|l|}
\hline & Making positive statements & \multirow{2}{*}{ Encouraging yourself } & \multirow{2}{*}{ Affective Strategies } \\
\hline & Taking risks wisely & & \\
\hline & Rewarding yourself & \multirow{2}{*}{$\begin{array}{l}\text { Taking your emotional } \\
\text { temperature }\end{array}$} & \\
\hline & $\begin{array}{c}\text { Using a checklist } \\
\text { Writing a Language learning diary } \\
\end{array}$ & $\begin{array}{c}\text { Discussing your feelings with } \\
\text { someone else }\end{array}$ & \\
\hline
\end{tabular}

Related to reading comprehension, Philip (2000:245) states that there are some skills in reading comprehension that consists on finding the main idea, recognizing the organization of ideas, finding stated details, finding unstated details, finding pronoun referents finding implied details, finding transitions implied details, finding definition of structural clues, determining meaning from word parts, using context to determine meaning of difficult words, using context to determine meaning of simple words, determining where specific information is found, and determining the tone, purpose, or course. Morever, comprehension skills are vital to reading process. True comprehension involves analyzing aspects of a text far beyond the simple details of the story, Cochran 1993:58. Then, developing learners are ready to face advanced comprehension skills in the areas of literal comprehension, inferential comprehension, and critical thinking.

Reading comprehension integrates various kinds of skills in order to arrive at the meaning of the text, soreading comprehension is the process of grasping the idea the author wants to inform by using some reading strategies, Nunan (1995) In line with this, Brown (1994) suggests that to develop students' reading comprehension in the classroom, the students may use some various learning strategies by themselves. There are some indicators of good reading comprehension of students; finding topic, topic sentence, main ideas, identifying details or information implicitly and explicitly, and guessing meaning of words, phrases, sentences and references based on the text. It can be concluded that the students may vary their efforts to make them successful in reading comprehension by applying appropriate language learning strategies.

\section{METHOD}

In this research, the participants were 42 students of English department students of college who have studied Reading comprehension III as their main subjects. To collect data, the students were given questionnaire SILL; the Strategy Inventory for Language Learning, Oxford (1990). It is one of the questionnaires, a standardized measure with versions for students of a variety of languages, and as such can be used to collect and analyze information about large numbers of language learners, (Chamot, 2004). Then, interview is done to the participants to know the factors that influence the learners in using affective language learning strategies in their reading comprehension that include (1) the informal conversational interview, (2) the general interview guide approach, and (3) the standardized open-ended interview.

In analysis of data, the researcher uses qualitative and quantitative analysis. Questionnaire is analyzed quantitatively by using the table below. The researcher analyzes the data as shown in the table below on the types of learning strategy used, the category of learning strategy used, the frequency, and the strategy items and some others.

Table 2. Key to understand the score of Learning Strategy (Oxford, 1990)

\begin{tabular}{|l|l|l|}
\hline Category & Choice of answer & Average score \\
\hline \multirow{2}{*}{ High } & Always or almost always used & $4,5-5,0$ \\
\cline { 2 - 3 } & Usually used & $3,5-4,4$ \\
\hline \multirow{2}{*}{ Ledium } & Sometimes used & $2,5-3,4$ \\
\hline & Generally used & $1,5-2,4$ \\
\cline { 2 - 3 } & Never or almost never used & $1,0-1,4$ \\
\hline
\end{tabular}

The qualitative data were collected by using interview that was made based on the principles introduced by Gall, Meredith, Gall Joyce P and Borg Walter R (2003), that is the general interview guide approachbased on the research question It is used to know the factors that influence the learners in using language learning strategies in their reading comprehension.

\section{FINDINGS AND DISCUSSION}

Based on the analysis of data, it was found that the students usesvarious affective learning strategies on their reading comprehension. Fromten strategy items of affective learning strategy, there were 4 items categorized high, two items categorized medium and four item categorized low. In general, for affective learning strategy, the students still applied affective learning strategies on the category medium. 
Table 3 The use of affective learning strategy items in English reading comprehension by college learners

\begin{tabular}{|c|c|c|c|c|c|c|c|c|c|}
\hline NO & Strategy items & Strategy Sets & $\%$ & \multicolumn{2}{|c|}{ Strategy Group } & AN & $\mathbf{H}$ & $\mathbf{M}$ & $\mathbf{L}$ \\
\hline 1 & $\begin{array}{l}\text { Using progressive } \\
\text { relaxation, deep } \\
\text { breathing or mediation }\end{array}$ & \multirow{3}{*}{$\begin{array}{l}\text { Lowering } \\
\text { your anxiety }\end{array}$} & \multirow[t]{3}{*}{3.05} & \multirow{10}{*}{$\begin{array}{l}\text { Affective } \\
\text { Learning } \\
\text { Strategies }\end{array}$} & \multirow{10}{*}{3,92} & 3.19 & & M & \\
\hline 2 & Using music & & & & & 2.44 & & & $\mathrm{~L}$ \\
\hline 3 & Using laughter & & & & & 3.57 & $\mathrm{H}$ & & \\
\hline 4 & $\begin{array}{c}\text { Making positive } \\
\text { statements }\end{array}$ & \multirow{3}{*}{$\begin{array}{l}\text { Encouraging } \\
\text { yourself }\end{array}$} & \multirow{3}{*}{3.28} & & & 4.13 & $\mathrm{H}$ & & \\
\hline 5 & Taking risks wisely & & & & & 3.50 & $\mathrm{H}$ & & \\
\hline 6 & Rewarding yourself & & & & & 2.19 & & & $\mathrm{~L}$ \\
\hline 7 & Listening to your body & \multirow{4}{*}{$\begin{array}{l}\text { Taking your } \\
\text { emotional } \\
\text { temperature }\end{array}$} & \multirow{4}{*}{2.71} & & & 4.10 & $\mathrm{H}$ & & \\
\hline 8 & Using a checklist & & & & & 2.00 & & & $\mathrm{~L}$ \\
\hline 9 & $\begin{array}{l}\text { Writing a Language } \\
\text { learning diary }\end{array}$ & & & & & 2.00 & & & $\mathrm{~L}$ \\
\hline 10 & $\begin{array}{l}\text { Discussing your } \\
\text { feelings with someone } \\
\text { else }\end{array}$ & & & & & 2.94 & & M & \\
\hline
\end{tabular}

\section{The distribution of the use of affective learning strategy items in English reading comprehension by college learners}

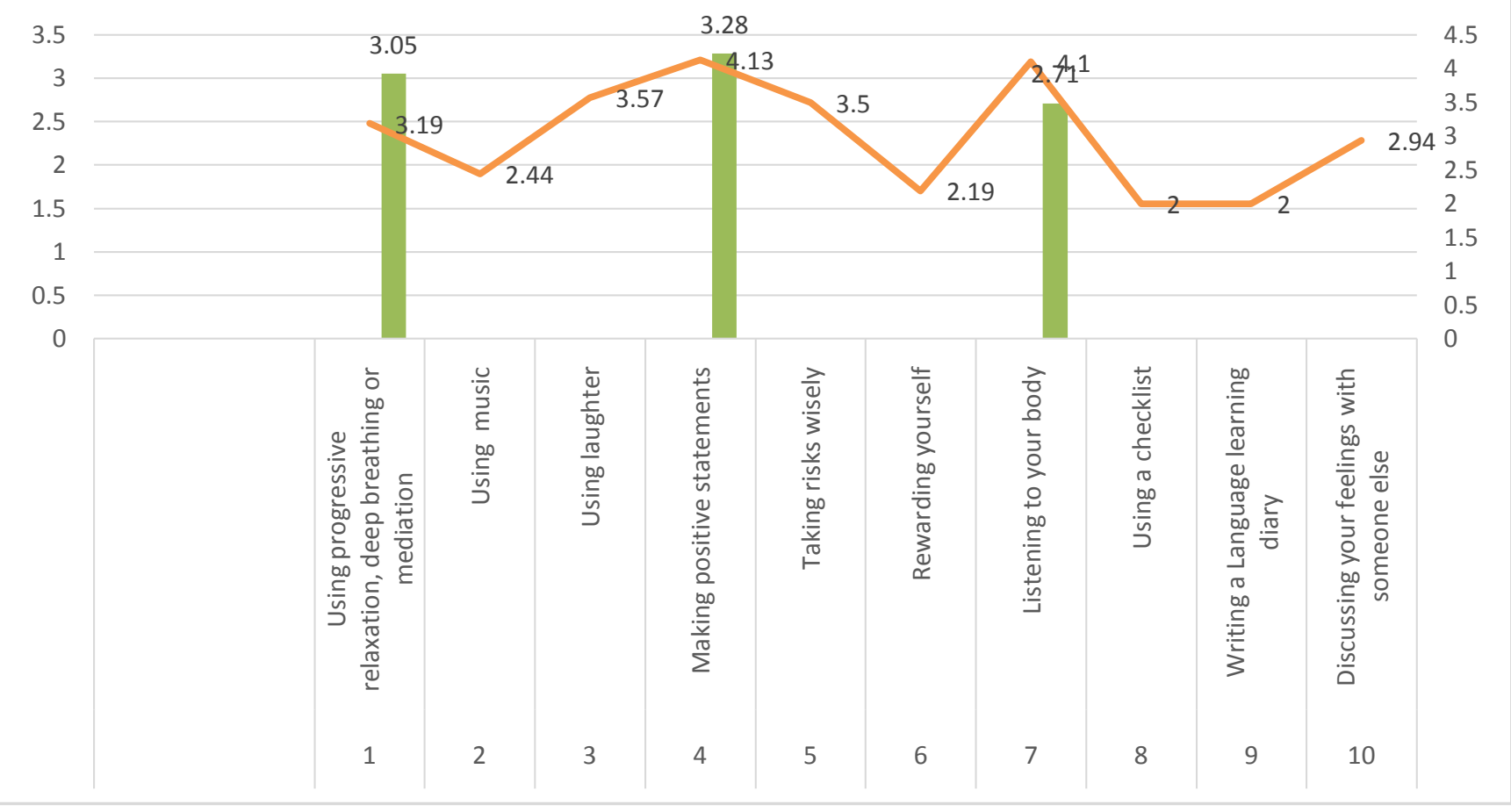

Fig. 1. The distribution of the use of affective learning strategy items in English reading comprehension by college learners 
From the chart above, it can be seen that among the three strategy sets of affective learning strategy used by the students in their reading cmprehension, encouraging yourself is the mostly used strategy by the students with the score of 3.28 , labelled as high.The lowest one is taking your emotional temperature with the score of 2.71 , labelled as Medium. Then, from the ten strategy items, making positive statements ismostly used strategy with the highest score of 4.13 , labelled as high, whileusing a checklist and writing a language learning diary are the least used strategy with the lowest score the of 2.00, labelled as low.

Then there are six factors that influence the students in using affective learning strategies in their reading comprehension. They are:

a. Motivation.

Based on the interview with the learners, it was found that motivation is important for them in using learning strategy in English reading comprehension. They used many strategies whenever they had high motivation in reading. In other words, motivation has influenced them in using language learning strategy in reading comprehension.

b. Attitudes and belief

The individual beliefs of learners in language learning reading comprehension is important and it influence them in using appropriate leaning strategy in reading comprehension. Based on the interview with the learners, it was found that the learners who had positive attitude and belief toward reading comprehension, tended to use many and good learning strategy in their reading comprehension.

c. Type of taskand assignment

The learners used learning strategy when they did the task or assignment on their reading comprehension. The form of task determined what learning strategy would be suitable with the task itself. Based on the interview the learners stated that in general the kind of task influenced them in using language learning strategy in reading comprehension.

d. Reading material

Based on the answer of open-ended questionnaire given to the learners, it was found that reading material was important in reading comprehension and it was one of the factors that influenced them to use language learning strategies in English reading comprehension. It can be seen from the open - ended questions given to the learners and the learners' answer or comments about reading material in relation to learning strategy in English reading comprehension.

e. Teaching media.

Based on the answer of open ended question given to the learners, it was found that the learners have answered differently. Some learners believed that teaching media was a very important one in learning reading comprehension and it influenced to the use certain learning strategy in reading. Some others were sure that teaching media was not so important for them.

f. The classroom activities

Some learners believed that classroom activities was important thing in their reading comprehension and it influenced them to use learning strategy in reading.

\section{CONCLUSION}

There were ten affective learning strategies that were concerned with the learner's emotional requirements. Among the ten of affective learning strategy items, the highest average score of learning strategy of learners was making positive statements and the lowest ones were using checklist and writing language learning diary. There were six influential factors of the learners in using certain language learning strategy; motivation, attitude and belief, type of task and assignment, reading material, teaching media and classroom activities. All factors were considered to give effects on the learners in their reading comprehension activities in or outside of the classroom. There were five reasons to use affective language learning strategy of English reading comprehension by the learners. They are to be easy to comprehend the reading, to vary the learning strategy in reading comprehension, to understand the text deeply, to imitate the friend in using the strategy, and to feel relax in reading.

The implication is the students need to be informed about the language learning strategies in reading comprehension and using appropriate language learning strategies in reading comprehension is considered to be one of the ways in improving the learners' reading comprehension achievement.Then, the lecturers should inform various learning strategies to the learners in teaching and learning activities because the learners have different language learning strategies of their owns.

\section{References}

Brown H. Douglas. (1994). Teaching by Principle: An Active Approach to LanguagePedagogy. Englewood Cliffs, New Jersey: Prentice Hall Regents.

Brown, Douglas, H. (2007). Principles of Language Learning and Teaching.New York: Pearson Education, Inc.

Chamot.et all. (1999). The Learning Strategies Handbook. New York: Addison Wesley Longman.

Chamot, Anna Uhl. (2004). Issues in Language Learning Strategy Research and Teaching. Retrieved on http://eflt.nus.edu.sg/v1n12004/chamot.htm at August 6, 2011.

Cohen, A. D. (1998). Strategies in Learning and Using a Second Language. London: Longman. 
Cochran, Judith. (1993). Everything You Need to Know to be a Successful Whole Language Teacher. Tennessee: Incentive Publications, Inc.

Lessard-Clouston, M. (1997). Language Learning Strategies: An overview for 12 teachers. Availableat: http://iteslj.org/Articles/Lessard-Clouston-Strategy.html

Nunan, D. (1995). Learner Strategy Training in the Classroom: An action research study. TESOL Journal, 6(1), 35-41.

O'Malley, J. M., \& Chamot, A. U. (1990). Learning Strategies in Second Language Acquisition. Cambridge, UK: Cambridge University Press.

Oxford, R. L. (1989). Use of Language Learning Strategies: A synthesis of studies with implications for strategytraining. System 17, 235-247.

Oxford, Rebecca L. (1990). Language Learning Strategies: What Every Teacher Should Know. New York: Newbury House Publishers.

Oxford, Rabecca.L. (1990b). Language Learning Strategies: What every teacher should know. Boston: Heinle\&Heinle.

Rubin, J., \& Thompson, I. (1994). How to Be a More Successful Language Learner (2nd ed.). Boston, MA: Heinle\&Heinle

Rubin, J. (1987). Learner Strategies: Theoretical Assumptions, Research History, and Typology. In A. L. Wenden\& J. Rubin (eds.), Learner Strategies in Language Learning (pp. 15-30). Englewood Cliffs: Prentice-Hall.

Whorther, T. Kathleen. 1986. Guide to College Reading. Niagara: Niagara Country. 